\title{
Selenium Addition to Colostrum Increases Immunoglobulin G Absorption by Newborn Calves
}

\author{
H. Kamada, ${ }^{* 1,2}$ I. Nonaka, $\dagger$ Y. Ueda, ${ }^{*}$ and M. Murai ${ }^{\star}$ \\ *National Agriculture Research Center for Hokkaido Region, Hitsujigaoka-1, Sapporo, Hokkaido, 062-8555, Japan \\ †National Institute of Livestock and Grassland Science, Tsukuba, Ibaraki, 305-0901, Japan
}

\begin{abstract}
The objective of this study was to show a new function of Se in IgG absorption from colostrum by newborn calves. The same amount and quality of colostrum with or without Se addition was fed to paired calves $(\mathrm{n}=60)$ 4 times at $<2,12,24$, and $36 \mathrm{~h}$ after birth, respectively. Four-time feeding of colostrum containing $1.0 \mathrm{ppm}$ Se significantly increased IgG amount in the blood plasma of calves $24 \mathrm{~h}$ after birth; however, its effect was small (about 20\% increase). Although the addition of $3.0 \mathrm{ppm}$ Se once at the first colostrum feeding was more effective on IgG absorption, its significant effect was a $42 \%$ increase on average. The increased IgG concentration of blood plasma continued for about 2 wk. It is known that the absorption of colostrum IgG is mediated by intestinal pinocytosis, which continues for only $24 \mathrm{~h}$ after birth. The addition of Se to colostrum might directly activate this physiological pinocytosis of intestinal epithelial cells because of the rapidity of the reaction. This effect is not nutritional but rather pharmacological. Supplemented Se also resulted in its increased concentration in blood plasma. Selenium is an essential mineral for animals; however, newborn calves are always deficient in Se at birth. Application of this method in calves would also provide an immediate supply of Se and might contribute to the development of the immune system of calves. This study showed that Se supplementation to colostrum increased IgG amount and Se concentration in blood plasma in newborn calves.
\end{abstract}

Key words: selenium, immunoglobulin G, colostrum, calf

\section{INTRODUCTION}

The mortality rate of newborn calves is still high, with reported values of $7.8 \%$ in the United Kingdom

Received May 8, 2007.

Accepted August 21, 2007.

${ }^{1}$ Corresponding author: kama8@affrc.go.jp

${ }^{2}$ Present address: National Institute of Livestock and Grassland Science, Tsukuba, Ibaraki, 305-0901, Japan.
(Esslemont and Kossaibati, 1996), 9.4 to $13.1 \%$ in the United States (Losinger and Heinrichs, 1997; Moore et al., 2002), and 6.3\% in Japan (Agricultural Mutual Relief Association of Hokkaido, 2002). One of the reasons for the high mortality of newborn calves is their susceptibility to infections. They do not have an available humoral immune system before ingesting colostrum from their dam, and their own immune system cannot react effectively with any antigens. If calves do not receive a sufficient amount of colostrum, they fall into hypogammaglobulinemia. Suffering calves have high sensitivity to infectious diarrhea and pneumonia, so their mortality is high. Therefore, the importance of colostral IgG supply is emphasized in animal husbandry; however, various reasons (low colostrum production, low IgG concentration in the colostrum, lack of instinctive suckling by the calf or dam, and physical injury to the calf) may prevent sufficient IgG transfer from the colostrum to calves (Perino et al., 1995; Weaver et al., 2000; Moore et al., 2005). It is known that pinocytosis of intestinal epithelial cells mediates the active transfer of IgG from the maternal colostrum to newborn calves (Kruse, 1983; Kaup et al., 1996); however, the ability of cells to pinocytose proteins disappears within $24 \mathrm{~h}$ after delivery. This means that a delay of providing colostrum also interferes with effective IgG absorption. Supplying a sufficient amount of IgG to newborn calves is largely dependent on human activities now; however, there is no available technique to increase the efficiency of IgG transfer.

Selenium has attracted much attention recently in animal nutrition, including human nutrition (Allan et al., 1999). It exerts various effects in vivo (Kamada and Hodate, 1998; Tan et al., 2002; Kellen et al., 2006). Among them, it is known that Se influences the immune response in several species of animals via the activation of phagocytosis by neutrophils, increased antibody production, and enhanced lymphocyte proliferation (Spears, 2000; Panousis et al., 2001). Because calves are always born with Se deficiency, feeding Se after birth is an important technique for promoting the development of their own immune system and thereby promoting their healthy growth. This study was conducted 
to develop a new method using Se to increase the blood IgG concentration of calves.

\section{MATERIALS AND METHODS}

\section{Experimental Design}

All procedures were approved by the Animal Care and Use Committee of the National Institute of Livestock and Grassland Sciences. Thirty pairs $(n=60)$ of Holstein calves born in our institute were used for experimental purposes. Colostrum supplemented with Se was administered to 1 of the 2 calves in a pair, and colostrum without Se was administered to the other calf. To equalize the experimental conditions of these sets of calves, they were selected based on their proximities in BW, which ranged from 30.8 to $56.9 \mathrm{~kg}$, and the differences between BW within a pair were less than $2.5 \mathrm{~kg}$. To avoid different rates of absorption of Ig due to different types of colostrum, the same amount of colostrum milked from 1 cow was fed to the 2 calves in a pair. The colostrum (frozen in a bottle at $-20^{\circ} \mathrm{C}$ until use) was of the following 4 types: the first milking postparturition (colostrum 1), the second milking postparturition (colostrum 2), the third milking postparturition (colostrum 3), and the fourth milking postparturition (colostrum 4). One liter of colostrum 1 was fed within $2 \mathrm{~h}$ of postparturition, and then $2 \mathrm{~L}$ of colostrum 2,3 , and 4 was fed, respectively, 12,24 , and $36 \mathrm{~h}$ postparturition. The concentration of IgG in the colostrum was 24.3 to $129.0 \mathrm{mg} / \mathrm{mL}$. Calves were kept in an individual indoor pen during the experimental period and were not fed anything apart from colostrums for first $48 \mathrm{~h}$. The experiments described above were carried out while varying the Se content based on the number of additions of Se; that is (experiment 1), adding Se (sodium selenite) to all 4 types of colostrum (0.2 to 5.0 $\mathrm{ppm}$ ) and (experiment 2) adding Se only to colostrum 1 (1.0 to $5.0 \mathrm{ppm}$ ). Plural supplementation was carried out to investigate the possibility of extension of physiological IgG absorption period by Se. The concentration of Se in the colostrum before adding Se was 0.06 to 0.1 ppm. Blood sampling was carried out 0,24 , and $48 \mathrm{~h}$ and $1 \mathrm{wk}$ and $2 \mathrm{wk}$ postparturition to investigate the effects of Se on IgG absorption and the changes of IgG and Se concentrations of blood plasma.

\section{Analytical Methods}

Selenium concentrations were determined by a fluorometric method using 2,3-diaminonaphtalene (Hoffman et al., 1968). Samples were digested with nitric acid and perchloric acid. After hydroxylamine and EDTA solutions were added to the digesta, the $\mathrm{pH}$ of the mixed solution was adjusted to 1.0 to 1.5 . Then, 2,3-diaminonaphtalene solution was added. This mixed solution was warmed at $50^{\circ} \mathrm{C}$ for $25 \mathrm{~min}$ in a semi-dark room and extracted with $n$-hexane after cooling. The fluorescence intensity of the organic phase was measured. Standard Se solution (WAKO Pure Chemical Industries Ltd., Osaka, Japan) treated with the same method was used for calibration.

The concentrations of IgG in the colostrum and plasma of calves were measured by radial immunodiffusion (The Binding Site Ltd., Birmingham, UK). Five microliters of diluted plasma samples $(\times 20)$, colostrum $(\times 50)$, and standard calibrators were applied to the gel. After incubation for $72 \mathrm{~h}$ at room temperature, ring diameters were measured. The total amount of IgG transferred to calves was normalized by the plasma volume, which was $9.1 \%$ of the BW of calves (Quigley et al., 1998).

The concentrations of $\alpha$-LA were measured by enzyme-linked solvent assay (Bethyl Laboratories Inc., Montgomery, TX). Diluted plasma samples and standards of $\alpha$-LA were transferred to assigned wells coated with capture antibody (goat anti-bovine $\alpha$-LA-affinity purified). After incubation and washing, diluted goat anti-bovine $\alpha$-LA-horseradish peroxidase conjugates were transferred to each well. After incubation, they were washed and then tetramethyl benzidine peroxidase substrate solution was added. The enzyme reactions were stopped by $2 M \mathrm{H}_{2} \mathrm{SO}_{4}$ after incubation. Using a microtiter plate reader, absorbance at $450 \mathrm{~nm}$ was measured. Biological parameters of blood plasma were measured by Hitachi Automatic Analyzer 7250 (Hitachi Ltd., Tokyo, Japan).

\section{Statistical Analysis}

Measurements are average values of calves within a test set, each set ranging from 2 to 5 pairs of calves. Lots of colostrum and BW of calves were different between pairs, so all data were tested using paired $t$ test. Differences between treatments were considered significant when $P<0.04$, whereas when $P>0.04$ but $<0.09$, differences were considered to indicate a trend toward a significant effect.

\section{RESULTS AND DISCUSSION}

To investigate the possibility that continuous stimulation of IgG absorption by the plural times of Se supplementation may result in the maximum increase of the amount of IgG transferred from colostrum to calves, colostrum mixed with Se was fed to calves 4 times at first (experiment 1). A wide range of Se concentrations $(0.2,1.0,5.0 \mathrm{ppm})$ was used in this experiment. The compensatory amount for the nutritional requirement 

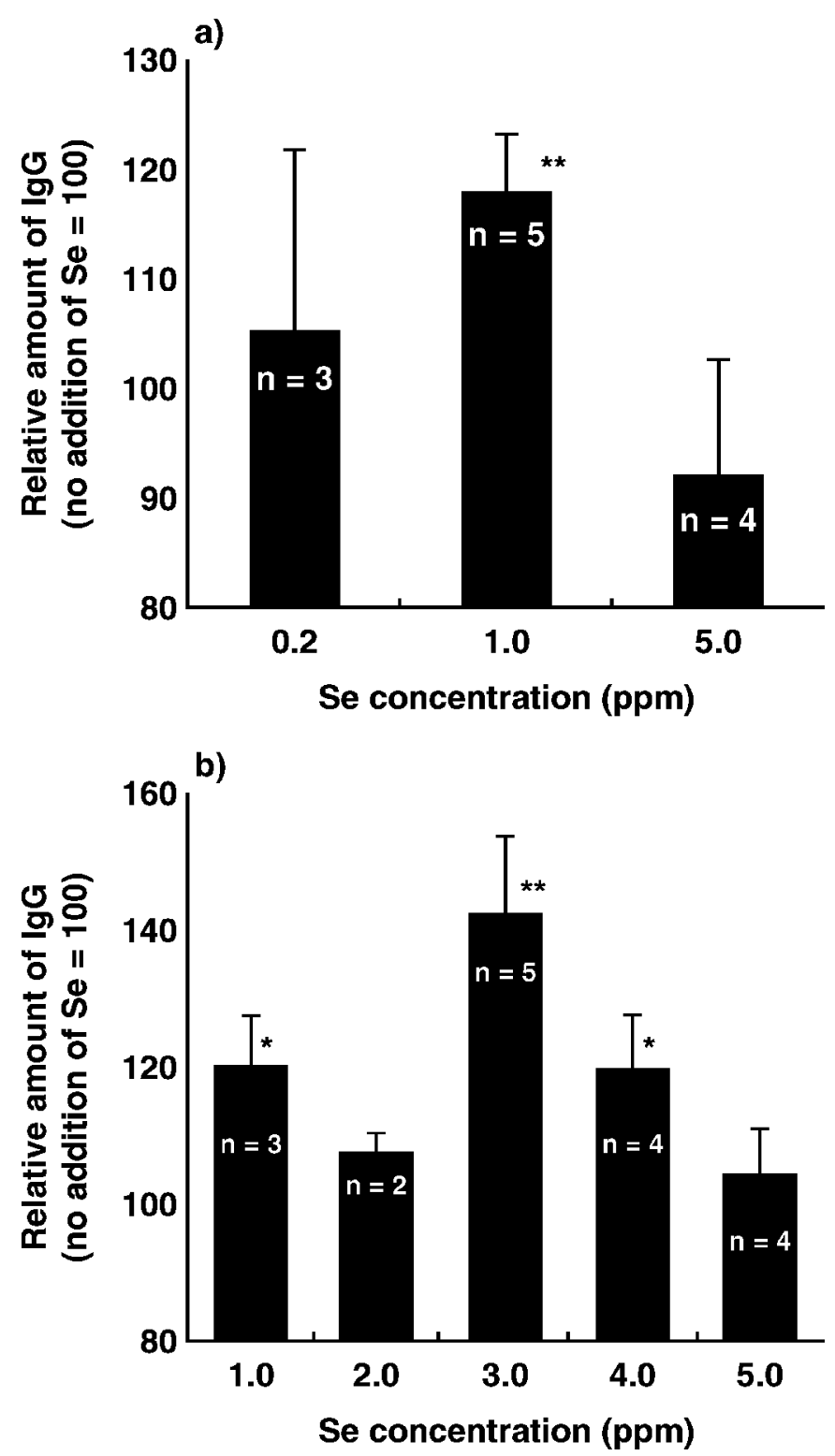

Figure 1. Effect of Se on the amount of IgG transferred from colostrum to blood plasma of calves $24 \mathrm{~h}$ postparturition. a) Supplementation of Se 4 times $(n=24)$. b) Supplementation of Se 1 time $(\mathrm{n}=36$ ). Maximum effects of Se on IgG absorption were observed 24 $\mathrm{h}$ after birth. Data were shown as the percentages for the control (no Se supplementation). The total number of pairs examined is shown in bars. The values are means \pm standard error of the means. Data were analyzed by paired $t$-test $\left(2\right.$-tailed). $* P<0.09$; ${ }^{*} P<0.04$.

recommended by the National Research Council (2001) is $0.2 \mathrm{ppm}$ of Se, because colostrum usually contains about $0.1 \mathrm{ppm}$ or lower of Se, and $5.0 \mathrm{ppm}$ addition is likely to be the limit to avoid poisoning as reported by Jenkins and Hidiroglou (1986). Consequently, 0.2 ppm addition of Se showed a small effect; however, Se at a 5 -fold concentration (1.0 ppm) significantly increased IgG absorption about $20 \%$ more than the control $(P=$

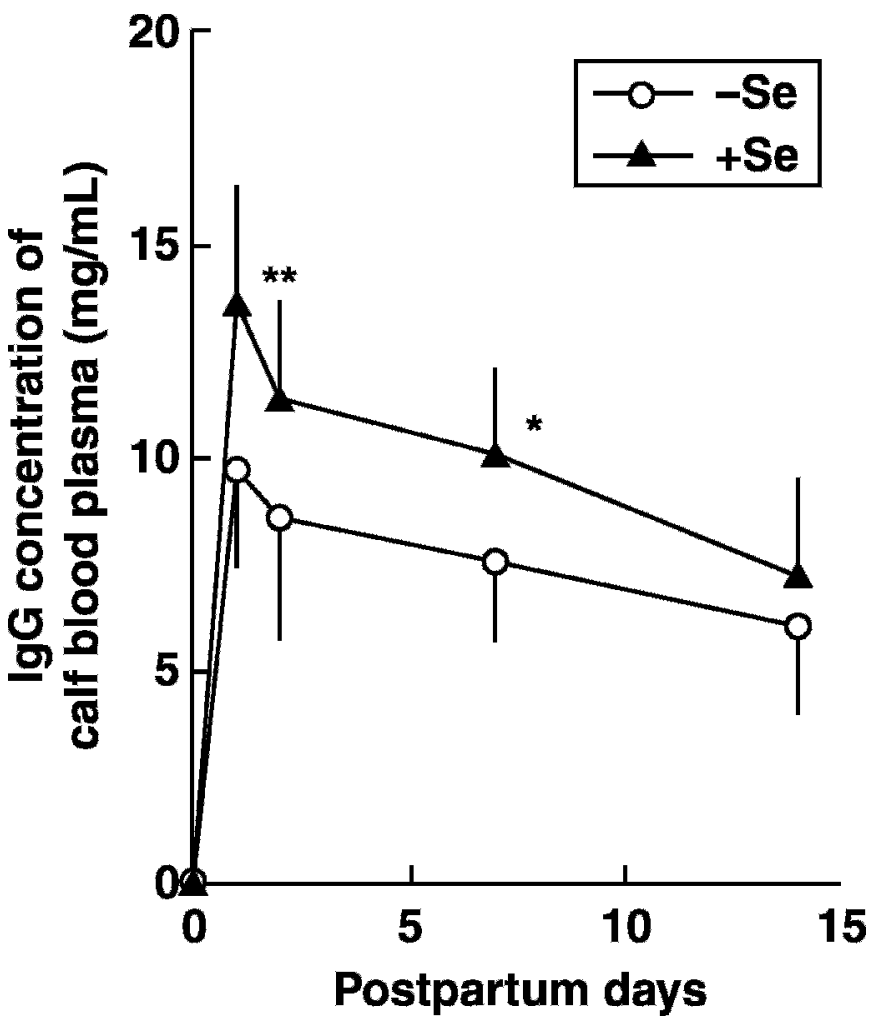

Figure 2. Changes of blood IgG concentration of calves with ( $\mathbf{\Delta})$ or without $(\bigcirc)$ Se supplementation. The blood IgG concentration of calves was increased and maintained for $2 \mathrm{wk}$ by Se supplementation (3.0 ppm, 1-time feeding; $\mathrm{n}=10$ ). Data were analyzed by paired $t$ test (2-tailed). $* P<0.09 ; * * P<0.04$. Error bars indicate standard errors of the means.

0.0188). Further high concentration $(5.0 \mathrm{ppm})$ of $\mathrm{Se}$ inhibited absorption (Figure 1a).

Because an excessive amount of Se showed a negative effect, Se was added once to the first colostrum feed in experiment 2. One-time feeding of Se was as effective as or more effective than 4-time feedings (Figure 1b). The maximum effect was observed in the case of 3.0 ppm Se feeding $(P=0.0296)$, at which the increase of the IgG level relative to the control level was $42 \%$ on average. The maximum increase was $75 \%$. This effect was not transient but lasted for about 2 wk (Figure 2). It takes about 1 mo for calves to develop their own immune system, so this technique can compensate for low resistance to some pathogens in this period.

Because plural time of Se supplementation was not needed to increase the efficiency of IgG absorption, feeding colostrum mixed with Se before the peak of physiological IgG absorption (8 to $12 \mathrm{~h}$ after birth) would be important. It is likely that further supplementation of Se $(12,24$, and $36 \mathrm{~h}$ after birth) had a small or no effect on IgG absorption and did not extend the period of its 
Table 1. Effects of Se supplementation $(3.0 \mathrm{ppm})$ on biochemical parameters of the blood of calves $(\mathrm{n}=8)$

\begin{tabular}{|c|c|c|c|c|c|c|}
\hline \multirow[b]{2}{*}{ Item $^{1}$} & \multirow[b]{2}{*}{$\mathrm{Se}$} & \multicolumn{5}{|c|}{ Time after birth } \\
\hline & & $0 \mathrm{~h}$ & $24 \mathrm{~h}$ & $48 \mathrm{~h}$ & $1 \mathrm{wk}$ & $2 \mathrm{wk}$ \\
\hline $\begin{array}{l}\text { GOT } \\
\text { (IU/L) }\end{array}$ & $\begin{array}{l}+\mathrm{Se} \\
-\mathrm{Se}\end{array}$ & $\begin{array}{l}18.2 \pm 4.0 \\
14.7 \pm 1.9\end{array}$ & $\begin{array}{l}98.8 \pm 27.4 \\
66.3 \pm 10.1\end{array}$ & $\begin{array}{l}64.9 \pm 16.9 \\
54.5 \pm 14.4\end{array}$ & $\begin{array}{l}31.7 \pm 5.8 \\
30.4 \pm 7.4\end{array}$ & $\begin{array}{l}29.1 \pm 6.8 \\
24.5 \pm 3.7\end{array}$ \\
\hline $\begin{array}{l}\text { GPT } \\
\text { (IU/L) }\end{array}$ & $\begin{array}{l}+\mathrm{Se} \\
-\mathrm{Se}\end{array}$ & $\begin{array}{l}5.1 \pm 1.0 \\
4.5 \pm 0.6\end{array}$ & $\begin{array}{l}18.3 \pm 9.1 \\
10.4 \pm 1.5\end{array}$ & $\begin{array}{l}18.6 \pm 1.0 \\
14.3 \pm 9.3\end{array}$ & $\begin{array}{r}10.2 \pm 3.1 \\
9.6 \pm 3.1\end{array}$ & $\begin{array}{l}6.8 \pm 3.0 \\
5.5 \pm 2.0\end{array}$ \\
\hline $\begin{array}{l}\mathrm{LDH} \\
\text { (IU/L) }\end{array}$ & $\begin{array}{l}+\mathrm{Se} \\
-\mathrm{Se}\end{array}$ & $\begin{array}{l}483 \pm 79 \\
408 \pm 55\end{array}$ & $\begin{aligned} 1,036 & \pm 330 \\
650 & \pm 80\end{aligned}$ & $\begin{array}{l}894 \pm 318 \\
641 \pm 88\end{array}$ & $\begin{array}{l}658 \pm 219 \\
574 \pm 114\end{array}$ & $\begin{array}{l}540 \pm 126 \\
514 \pm 36\end{array}$ \\
\hline $\begin{array}{l}\text { ALP } \\
\text { (IU/L) }\end{array}$ & $\begin{array}{l}+\mathrm{Se} \\
-\mathrm{Se}\end{array}$ & $\begin{array}{l}502 \pm 132 \\
686 \pm 155\end{array}$ & $\begin{array}{l}1,305 \pm 540 \\
1,951 \pm 958\end{array}$ & $\begin{array}{l}825 \pm 414 \\
995 \pm 280\end{array}$ & $\begin{array}{l}605 \pm 179 \\
923 \pm 238\end{array}$ & $\begin{array}{l}604 \pm 117 \\
647 \pm 58\end{array}$ \\
\hline $\begin{array}{l}\text { Glucose } \\
(\mathrm{mg} / \mathrm{dL})\end{array}$ & $\begin{array}{l}+\mathrm{Se} \\
-\mathrm{Se}\end{array}$ & $\begin{array}{l}121 \pm 25 \\
103 \pm 35\end{array}$ & $\begin{array}{l}120 \pm 19 \\
121 \pm 9\end{array}$ & $\begin{array}{l}113 \pm 7 \\
118 \pm 12\end{array}$ & $\begin{aligned} 97 & \pm 19 \\
106 & \pm 8\end{aligned}$ & $\begin{array}{c}95 \pm 9 \\
101 \pm 17\end{array}$ \\
\hline $\begin{array}{l}\text { TG } \\
(\mathrm{mg} / \mathrm{dL})\end{array}$ & $\begin{array}{l}+\mathrm{Se} \\
-\mathrm{Se}\end{array}$ & $\begin{array}{l}4.8 \pm 2.2 \\
3.7 \pm 0.7\end{array}$ & $\begin{array}{l}32.5 \pm 13.2 \\
26.3 \pm 12.0\end{array}$ & $\begin{array}{l}51.0 \pm 17.6 \\
34.9 \pm 13.2\end{array}$ & $\begin{array}{l}29.1 \pm 12.1 \\
37.6 \pm 14.9\end{array}$ & $\begin{array}{l}23.1 \pm 4.3 \\
29.6 \pm 11.3\end{array}$ \\
\hline $\begin{array}{l}\text { NEFA } \\
(\mu \mathrm{Eq} / \mathrm{L})\end{array}$ & $\begin{array}{l}+\mathrm{Se} \\
-\mathrm{Se}\end{array}$ & $\begin{aligned} 8 & \pm 4 \\
50 & \pm 30\end{aligned}$ & $\begin{array}{l}351 \pm 172 \\
296 \pm 177\end{array}$ & $\begin{array}{l}378 \pm 179 \\
393 \pm 114\end{array}$ & $\begin{array}{l}248 \pm 144 \\
382 \pm 191\end{array}$ & $\begin{array}{l}199 \pm 147 \\
249 \pm 15\end{array}$ \\
\hline $\begin{array}{l}\text { BUN } \\
(\mathrm{mg} / \mathrm{dL})\end{array}$ & $\begin{array}{l}+\mathrm{Se} \\
-\mathrm{Se}\end{array}$ & $\begin{array}{r}11.3 \pm 3.3 \\
9.1 \pm 3.2\end{array}$ & $\begin{array}{r}10.0 \pm 2.9 \\
8.9 \pm 3.1\end{array}$ & $\begin{array}{l}8.4 \pm 3.9 \\
8.2 \pm 4.4\end{array}$ & $\begin{array}{l}9.8 \pm 4.5 \\
6.3 \pm 1.7\end{array}$ & $\begin{array}{r}11.8 \pm 3.0 \\
9.6 \pm 0.8\end{array}$ \\
\hline $\begin{array}{l}\text { Albumin } \\
(\mathrm{g} / \mathrm{dL})\end{array}$ & $\begin{array}{l}+\mathrm{Se} \\
-\mathrm{Se}\end{array}$ & $\begin{array}{l}2.9 \pm 0.2 \\
2.8 \pm 0.1\end{array}$ & $\begin{array}{l}2.7 \pm 0.2 \\
2.7 \pm 0.1\end{array}$ & $\begin{array}{l}2.8 \pm 0.2 \\
2.7 \pm 0.1\end{array}$ & $\begin{array}{l}3.1 \pm 0.2 \\
3.0 \pm 0.1\end{array}$ & $\begin{array}{l}3.3 \pm 0.4 \\
3.2 \pm 0.1\end{array}$ \\
\hline $\begin{array}{l}\text { T-CHO } \\
\text { (mg/dL) }\end{array}$ & $\begin{array}{l}+\mathrm{Se} \\
-\mathrm{Se}\end{array}$ & $\begin{array}{l}19.3 \pm 3.8 \\
16.0 \pm 3.3\end{array}$ & $\begin{array}{l}40.2 \pm 3.8 \\
32.8 \pm 2.9\end{array}$ & $\begin{array}{l}60.5 \pm 6.1 \\
50.4 \pm 6.0\end{array}$ & $\begin{array}{l}88.0 \pm 38.2 \\
88.8 \pm 3.8\end{array}$ & $\begin{array}{l}117.9 \pm 60.4 \\
120.8 \pm 29.2\end{array}$ \\
\hline $\begin{array}{l}\mathrm{T}-\mathrm{KB} \\
(\mu \mathrm{mol} / \mathrm{L})\end{array}$ & $\begin{array}{l}+\mathrm{Se} \\
-\mathrm{Se}\end{array}$ & $\begin{array}{r}104 \pm 55 \\
62 \pm 12\end{array}$ & $\begin{array}{r}92 \pm 18 \\
102 \pm 49\end{array}$ & $\begin{array}{r}96 \pm 17 \\
115 \pm 26\end{array}$ & $\begin{array}{l}112 \pm 49 \\
117 \pm 41\end{array}$ & $\begin{array}{l}112 \pm 37 \\
146 \pm 114\end{array}$ \\
\hline $\begin{array}{l}\text { Protein } \\
\text { (g/dL) }\end{array}$ & $\begin{array}{l}+\mathrm{Se} \\
-\mathrm{Se}\end{array}$ & $\begin{array}{l}4.5 \pm 0.4 \\
4.5 \pm 0.3\end{array}$ & $\begin{array}{l}5.8 \pm 1.0 \\
5.6 \pm 1.0\end{array}$ & $\begin{array}{l}5.9 \pm 0.9 \\
5.6 \pm 1.0\end{array}$ & $\begin{array}{l}6.0 \pm 0.6 \\
5.6 \pm 0.8\end{array}$ & $\begin{array}{l}5.8 \pm 0.7 \\
5.5 \pm 0.7\end{array}$ \\
\hline $\begin{array}{l}\text { Inorganic P } \\
(\mathrm{mg} / \mathrm{dL})\end{array}$ & $\begin{array}{l}+\mathrm{Se} \\
-\mathrm{Se}\end{array}$ & $\begin{array}{l}8.4 \pm 1.6 \\
7.1 \pm 1.2\end{array}$ & $\begin{array}{l}6.3 \pm 1.1 \\
6.9 \pm 0.8\end{array}$ & $\begin{array}{l}6.7 \pm 0.9 \\
7.5 \pm 0.5\end{array}$ & $\begin{array}{l}7.3 \pm 0.6 \\
7.9 \pm 0.3\end{array}$ & $\begin{array}{l}7.9 \pm 1.5 \\
8.2 \pm 0.4\end{array}$ \\
\hline $\begin{array}{l}\mathrm{Ca} \\
(\mathrm{mg} / \mathrm{dL})\end{array}$ & $\begin{array}{l}+\mathrm{Se} \\
-\mathrm{Se}\end{array}$ & $\begin{array}{l}12.8 \pm 1.1 \\
12.3 \pm 0.6\end{array}$ & $\begin{array}{l}10.9 \pm 0.9 \\
11.0 \pm 0.2\end{array}$ & $\begin{array}{l}11.4 \pm 0.8 \\
11.9 \pm 0.3\end{array}$ & $\begin{array}{l}10.4 \pm 0.8 \\
11.1 \pm 0.4\end{array}$ & $\begin{array}{l}10.3 \pm 0.7 \\
10.2 \pm 0.2\end{array}$ \\
\hline $\begin{array}{l}\mathrm{Fe} \\
(\mu \mathrm{g} / \mathrm{dL})\end{array}$ & $\begin{array}{l}+\mathrm{Se} \\
-\mathrm{Se}\end{array}$ & $\begin{array}{l}146 \pm 86 \\
137 \pm 59\end{array}$ & $\begin{array}{r}107 \pm 28 \\
94 \pm 49\end{array}$ & $\begin{array}{r}109 \pm 65 \\
85 \pm 64\end{array}$ & $\begin{array}{l}28 \pm 9 \\
47 \pm 33\end{array}$ & $\begin{array}{l}52 \pm 29 \\
75 \pm 78\end{array}$ \\
\hline $\begin{array}{l}\mathrm{Mg} \\
(\mathrm{mg} / \mathrm{dL})\end{array}$ & $\begin{array}{l}+\mathrm{Se} \\
-\mathrm{Se}\end{array}$ & $\begin{array}{l}2.3 \pm 0.3 \\
2.2 \pm 0.4\end{array}$ & $\begin{array}{l}2.2 \pm 0.3 \\
2.1 \pm 0.1\end{array}$ & $\begin{array}{l}2.1 \pm 0.2 \\
2.0 \pm 0.2\end{array}$ & $\begin{array}{l}2.0 \pm 0.1 \\
1.9 \pm 0.9\end{array}$ & $\begin{array}{l}2.0 \pm 0.1 \\
2.1 \pm 0.0\end{array}$ \\
\hline $\begin{array}{l}\mathrm{Na} \\
(\mathrm{mEq} / \mathrm{L})\end{array}$ & $\begin{array}{l}+\mathrm{Se} \\
-\mathrm{Se}\end{array}$ & $\begin{array}{l}142 \pm 1 \\
144 \pm 0\end{array}$ & $\begin{array}{l}139 \pm 2 \\
142 \pm 1\end{array}$ & $\begin{array}{l}139 \pm 1 \\
141 \pm 1\end{array}$ & $\begin{array}{l}137 \pm 4 \\
141 \pm 1\end{array}$ & $\begin{array}{l}140 \pm 3 \\
139 \pm 1\end{array}$ \\
\hline $\begin{array}{l}\mathrm{K} \\
(\mathrm{mEq} / \mathrm{L})\end{array}$ & $\begin{array}{l}+\mathrm{Se} \\
-\mathrm{Se}\end{array}$ & $\begin{array}{l}4.9 \pm 0.3 \\
4.8 \pm 0.2\end{array}$ & $\begin{array}{l}4.9 \pm 0.5 \\
4.6 \pm 0.2\end{array}$ & $\begin{array}{l}4.7 \pm 0.4 \\
4.7 \pm 0.2\end{array}$ & $\begin{array}{l}4.8 \pm 0.5 \\
4.6 \pm 0.2\end{array}$ & $\begin{array}{l}4.8 \pm 0.6 \\
4.5 \pm 0.1\end{array}$ \\
\hline $\begin{array}{l}\mathrm{Cl} \\
(\mathrm{mEq} / \mathrm{L})\end{array}$ & $\begin{array}{l}+\mathrm{Se} \\
-\mathrm{Se}\end{array}$ & $\begin{array}{l}96.1 \pm 4.2 \\
99.3 \pm 1.0\end{array}$ & $\begin{array}{l}95.6 \pm 1.6 \\
98.2 \pm 1.8\end{array}$ & $\begin{array}{l}96.8 \pm 1.5 \\
98.6 \pm 2.7\end{array}$ & $\begin{array}{l}95.0 \pm 2.8 \\
98.2 \pm 1.3\end{array}$ & $\begin{array}{l}96.0 \pm 1.9 \\
98.3 \pm 0.6\end{array}$ \\
\hline
\end{tabular}

${ }^{1} \mathrm{GOT}$ = glutamic oxaloacetic transaminase; GPT = glutamic pyruvic transaminase; $\mathrm{LDH}=$ lactate dehydrogenase; ALP = alkaline phosphatase; $\mathrm{TG}=$ triglyceride; $\mathrm{T}-\mathrm{CHO}=$ total cholesterol; $\mathrm{T}-\mathrm{KB}=$ total ketone body.

absorption. Thus, it is considered that the effect of Se is an enhancement of physiological IgG absorption.

Immunoglobulin $\mathrm{G}$ absorption is mediated by the pinocytosis of intestinal epithelial cells. Hardy (1969) measured the absorption of radioactive $\gamma$-globulin administered into the duodenum of anesthetized newborn calves. He reported that salts of some fatty acids showed a similar effect to colostrum whey on the absorption of $\gamma$-globulin. Among them, potassium isobutyrate at the concentration of $56.7 \mathrm{~m} M$ was most effective; however, this concentration was about 1,000 times higher than that of the Se used in our experiment $(3.0 \mathrm{ppm}=0.038$ $\mathrm{m} M$ ), and feeding colostrum mixed with potassium isobutyrate to calves did not increase IgG absorption in his experiment. These results indicate that the mechanisms of their effects on IgG absorption are different between Se and isobutyrate. Another researcher reported that Se and IgG form a complex in vitro (Burton et al., 1977). The structural change of Ig by the formation of a complex is likely to be advantageous for pinocytosis; however, the amount of Se showing enhanced IgG absorption was stoichiometrically smaller than that of IgG in colostrum. And colostrum contains many kinds of components without IgG, so added Se may not 
be able to form a complex with IgG in colostrum as efficiently as in their in vitro experiment. However, Pighetti et al. (1998) reported that internalization of transferrin receptor protein was suppressed in Se-deficient rats. This observation suggested the possibility that Se relates to the absorption of substances via cell membrane (internalization); however, the Se concentration needed in our experiment was greater than the recommended value $(0.3 \mathrm{ppm})$ to fulfill the nutrition requirement (National Research Council, 2001) of dairy cows. Also, the reaction of calves to Se feeding was immediate. These observations indicated that this effect of Se on IgG absorption is not nutritional but rather pharmacological. Enhancement of IgG absorption by Se cannot be explained by any of the known effects of Se (nutritionally or biochemically). It is likely that Se acts on the intestinal epithelium directly and activates its pinocytosis. The amount of $\alpha$-LA (non-Ig protein) in plasma $24 \mathrm{~h}$ postparturition also increased in the Se (3.0 ppm)-supplemented group (+Se: $5.44 \pm 1.19 \mathrm{mg}$, - Se: $2.99 \pm 0.91 \mathrm{mg}$ ). This observation might support the activation of pinocytosis by Se.

In this experiment, different types of colostrums were used among calf pairs to show that the Se effect on IgG absorption is observed with various types of (not specific) colostrum feeding. Our results showed that this phenomenon is not specific; however, the Se concentration showing maximum effect was not clear for the above reason. It is likely that the quality of colostrum affects the degree of increase of IgG absorption by Se. Further experiments (using the same lot of colostrum containing a wide concentration range of Se) are needed to determine the appropriate concentration of Se mixed with colostrum.

Although we feared that the addition of a high concentration of Se to colostrum might poison the calves, there were no problems with their health. When biochemical tests of the blood of calves fed $3.0 \mathrm{ppm}$ Se (showing a maximum effect on IgG absorption) were carried out, no abnormal values were observed (Table 1 ). The studied parameters related to energy metabolism, $\mathrm{N}$ metabolism, and mineral balance were not affected by Se supplementation at the used concentrations. Jenkins and Hidiroglou (1986) reported that feeding milk containing $5.0 \mathrm{ppm}$ Se for $40 \mathrm{~d}$ did not affect calves. It is concluded that there is no risk of Se poisoning to calves with this method and that Se mixed with colostrum becomes an available source for newborn calves with Se deficiency (Figure 3). Our technique therefore has 2 beneficial effects (increase of IgG absorption and of Se supply).

Animal farmers strongly wish to provide adequate Ig from colostrum to calves as soon as possible after birth, because colostrum feeding is almost the only method to protect calves from infections outside of rearing them

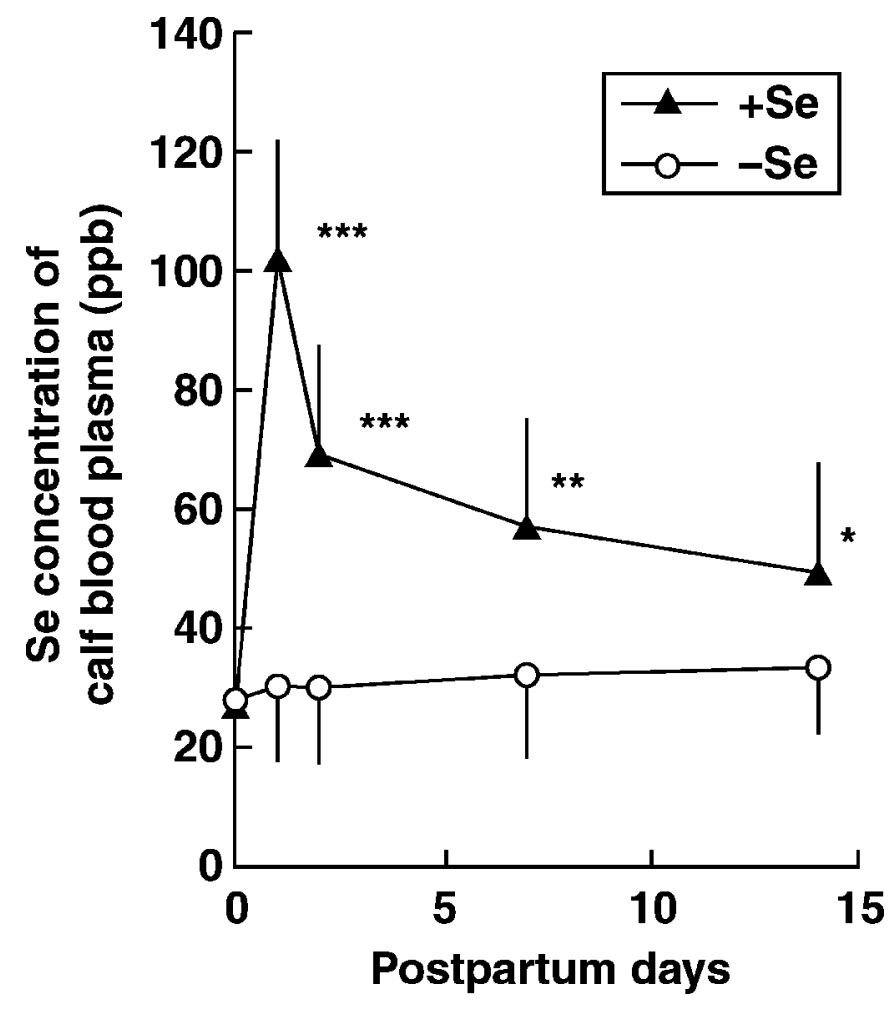

Figure 3. Changes of blood Se concentration of calves with ( $\mathbf{\Delta})$ or without $(\bigcirc)$ Se supplementation. The blood Se concentration of calves was increased and maintained for $2 \mathrm{wk}$ by Se supplementation $(3.0 \mathrm{ppm}, 1$-time feeding; $\mathrm{n}=8)$. Data were analyzed by paired $t$-test (2-tailed). $* P<0.04 ; * * P<0.01 ; * * * P<0.001$. Error bars indicate standard errors of the means.

under sanitary conditions. In an answer to their demands, colostrum powder, colostrum replacer, or colostrum supplement, which contain Ig, are sold commercially. The addition of Se to these products could increase the rate of IgG transfer to calves.

\section{CONCLUSIONS}

Our experiments showed that IgG absorption by newborn calves is enhanced by adding Se to colostrum and that the used concentrations of Se do not have any negative effects on calves. This phenomenon cannot be explained by any identified functions of Se. Increased IgG and Se in blood plasma could contribute to improve resistance to infectious diseases in postnatal calves and reduce the attrition rate.

\section{ACKNOWLEDGMENTS}

We wish to thank the staff of the Ruminant and Field Management Section of the National Institute of Livestock and Grassland Science and the National Agricul- 
ture Research Center for Hokkaido Region for their assistance with animal handling and care.

\section{REFERENCES}

Agricultural Mutual Relief Association of Hokkaido. 2002. Page 321 in Records of livestock insurance in 2002. Agricultural Mutual Relief Association of Hokkaido, Sapporo, Japan.

Allan, C. B., G. M. Lacourciere, and T. C. Stadtman. 1999. Responsiveness of selenoproteins to dietary selenium. Annu. Rev. Nutr. 19:1-16.

Burton, R. M., P. J. Higgins, and K. P. McConnel. 1977. Reaction of selenium with immunoglobulin molecules. Biochim. Biophys. Acta 493:323-331.

Esslemont, R. J., and M. A. Kossaibati. 1996. Incidence of production diseases and other health problems in a group of dairy herds in England. Vet. Rec. 139:486-490.

Hardy, R. N. 1969. The influence of specific chemical factors in the solvent on the absorption of macromolecular substances from the small intestine of the newborn calves. J. Physiol. 204:607-632.

Hoffman, I., R. J. Westerby, and M. Hidiroglou. 1968. Precise fluorometric microdetermination of selenium in agricultural materials. J. AOAC 51:1039-1042.

Jenkins, K. J., and M. Hidiroglou. 1986. Tolerance of the preruminant calf for selenium in milk replacer. J. Dairy Sci. 69:1865-1870.

Kamada, H., and K. Hodate. 1998. Effect of dietary selenium supplementation on the plasma progesterone concentration in cows. J. Vet. Med. Sci. 60:133-135.

Kaup, F. J., W. Drommer, K. Jochims, and M. Pickel. 1996. Ultrastructure of pre- and postcolostral entrocytes of the newborn calf. Anat. Histol. Embryol. 25:249-255.

Kellen, E., M. Zeegers, and F. Buntinx. 2006. Selenium is inversely associated with bladder cancer risk: A report from Belgian casecontrol study on bladder cancer. Int. J. Urol. 13:1180-1184.

Kruse, P. E. 1983. The importance of colostral immunoglobulins and their absorption from the intestine of the newborn animals. Ann. Rech. Vet. 14:349-353.
Losinger, W. C., and A. J. Heinrichs. 1997. Management practices associated high mortality among preweaned dairy heifers. J. Dairy Sci. 64:1-11.

Moore, M., J. W. Tyler, M. Chigerwe, M. E. Dawes, and J. R. Middleton. 2005. Effect of delayed colostrums collection on colostral IgG concentration in dairy cows. J. Am. Vet. Med. Assoc. 226:13751377.

Moore, D. A., M. S. William, D. M. Festa, J. P. Reynolds, E. R. Atwill, and C. A. Holmberg. 2002. Influence of arrival weight, season and calf supplier on survival in Holstein beef calves on a calf ranch in California, USA. Prev. Vet. Med. 53:103-111.

National Research Council. 2001. Nutrient Requirements of Dairy Cattle. 7th. rev. ed. ed. Natl. Acad. Press, Washington, DC.

Panousis, N., N. Roubies, H. Karatzias, S. Frydas, and A. Papasteriadis. 2001. Effect of selenium and vitamin $\mathrm{E}$ on antibody production by dairy cows vaccinated against Escherichia coli. Vet. Rec. 149:643-646.

Perino, L. J., T. E. Wittum, and G. S. Ross. 1995. Effects of various risk factors on plasma protein and serum immunoglobulin concentrations of calves at postpartum hours 10 and 24. Am. J. Vet. Res. 56:1144-1148.

Pighetti, G. M., M. L. Eskew, C. C. Reddy, and L. M. Sordillo. 1998. Selenium and vitamin E deficiency impair transferrin receptor internalization but not IL-2, IL-2 receptor, or transferrin receptor expression. J. Leukoc. Biol. 63:131-137.

Quigley, J. D., III, D. L. Fike, M. N. Egerton, J. J. Drewry, and J. D. Arthington. 1998. Effects of a colostrum replacement product derived from serum on immunoglobulin $\mathrm{G}$ absorption by calves. J. Dairy Sci. 81:1936-1939.

Spears, J. W. 2000. Micronutrients and immune function in cattle. Proc. Nutr. Soc. 59:587-594.

Tan, J., W. Zhu, W. Wang, R. Li, S. Hou, D. Wang, and L. Yang. 2002. Selenium in soil and endemic diseases in China. Sci. Total Environ. 284:227-235.

Weaver, D. M., J. W. Tyler, D. C. VanMetre, D. E. Hostetler, and G. M. Barrington. 2000. Passive transfer of colostral immunoglobulins in calves. J. Vet. Intern. Med. 14:569-577. 